\title{
Renal and pulmonary effects of angiotensin converting enzyme inhibition in chronic hypoxic lung disease
}

\author{
RICHARD M OLIVER, ANDREW J PEACOCK, JOHN S FLEMING, DEREK G WALLER \\ From the Clinical Pharmacology Group, Departments of Medicine and of Nuclear Medicine, Southampton \\ General Hospital, Southampton
}

ABSTRACT The effects of 28 days' treatment with captopril or with placebo on renal and pulmonary function were evaluated in nine patients with stable pulmonary heart disease. Captopril ( $25 \mathrm{mg}$ twice daily) caused a $17 \%$ rise in effective renal plasma flow but no change in glomerular filtration rate, resulting in a fall in filtration fraction likely to favour natriuresis. Captopril did not alter $\mathrm{FEV}_{1}$, lung volumes, or arterial oxygen or carbon dioxide tension.

\section{Introduction}

Hypoxaemia, with or without carbon dioxide retention, may precipitate the clinical syndrome of pulmonary heart disease in chronic obstructive lung disease, which is characterised by fluid retention and oedema. Although cardiac output is usually normal or increased, ${ }^{1}$ renal blood flow is reduced ${ }^{2}$ and the reninangiotensin-aldosterone system may be activated. ${ }^{3}$ Treatment with an angiotensin converting enzyme inhibitor may therefore reduce fluid retention during an exacerbation of pulmonary heart disease.

Improvements in forced vital capacity (FVC) and carbon monoxide gas transfer (TLCO) were found in an open study with captopril in patients with chronic obstructive lung disease ${ }^{4}$; these may be explained by a reduction in "lung water" and improved lung compliance. We have therefore investigated the effects of 28 days' treatment with captopril on renal haemodynamics and pulmonary function in a placebo controlled study in patients with stable pulmonary heart disease.

\section{Methods}

We studied nine patients (aged 53-72 years) with advanced chronic obstructive lung disease (mean (SEM) forced expiratory volume in one second $\left(\mathrm{FEV}_{1}\right)$

Address for reprint requests: Dr R M Oliver, Clinical Pharmacology Group, Southampton General Hospital (Centre Block), Southampton SO9 4XY.

Accepted 22 March 1989
$0.87(0 \cdot 11)$ litres) and hypoxaemia (mean arterial oxygen tension $\left.\left(\mathrm{PaO}_{2}\right) 7.87(0.52) \mathrm{kPa}\right)($ table 1$)$. All had a history of fluid retention during exacerbation of their pulmonary disease, but had no oedema at the time of study. Other cardiac or renal causes of oedema were excluded on clinical grounds. Patients with renal impairment or recent exacerbation of airflow obstruction were excluded. Diuretic treatment was withdrawn one week before the study, but in three patients had to be restarted before the study because oedema recurred. Patients continued inhaled bronchodilators, oral corticosteroids, and methylxanthine preparations in unchanged doses throughout the study. The study was approved by the local ethical committee and patients gave written informed consent.

The study was randomised, double blind, and crossover in design. Patients received either captopril $25 \mathrm{mg}$ twice daily or placebo for 28 days each. Assessments were performed on day 0 , day 28 , and day 56. At each visit body weight and supine and erect heart rate and systemic arterial blood pressure were documented. Venous blood was drawn for angiotensin II estimation. ${ }^{5}$ Radial artery puncture was performed to determine arterial $\mathrm{PaO}_{2}$ and carbon dioxide tension $\left(\mathrm{PaCO}_{2}\right)$ (Radiometer ABL3).

All pulmonary function tests were performed with the subjects seated, 10 minutes after they had received nebulised salbutamol $(2.5 \mathrm{mg})$. The recorded spirometric lung volumes $\left(\mathrm{FEV}_{1}\right.$ and FVC were the best of three observations and were expressed as percentages of predicted values. Alveolar volume (VA) and TLCO were estimated after single breath helium and carbon monoxide inhalation. Transfer coefficient ( $\left.\mathrm{TLCO} / \mathrm{VA}_{\mathrm{A}}=\mathrm{KCO}\right)$ was also calculated. Lung 
Table 1 Baseline data for the patients studied

\begin{tabular}{|c|c|c|c|c|c|c|c|c|c|c|}
\hline $\begin{array}{l}\text { Patient } \\
\text { No }\end{array}$ & Age/sex & $\begin{array}{l}\text { Diuretics } \\
\text { during } \\
\text { study }\end{array}$ & $\begin{array}{l}F E V_{1} \\
\text { (\% pred) }\end{array}$ & $\begin{array}{l}F V C \\
\text { (\% pred) }\end{array}$ & $\begin{array}{l}\mathrm{PaO}_{2} \\
(\mathrm{kPa})\end{array}$ & $\begin{array}{l}\mathrm{PaCO}_{2} \\
(\mathrm{kPa})\end{array}$ & $\begin{array}{l}\text { GFR } \\
(\mathrm{ml} / \mathrm{min})\end{array}$ & $\begin{array}{l}\text { ERPF } \\
(\mathrm{ml} / \mathrm{min})\end{array}$ & $F F$ & $\begin{array}{l}A I I^{*} \\
(\mathrm{pg} / \mathrm{ml})\end{array}$ \\
\hline $\begin{array}{l}1 \\
2 \\
3 \\
4 \\
5 \\
6 \\
7 \\
8 \\
9\end{array}$ & $\begin{array}{l}70 / \mathrm{M} \\
53 / \mathrm{M} \\
58 / \mathrm{M} \\
63 / \mathrm{F} \\
69 / \mathrm{F} \\
59 / \mathrm{M} \\
69 / \mathrm{M} \\
72 / \mathrm{F} \\
56 / \mathrm{F}\end{array}$ & $\begin{array}{l}\overline{-} \\
+ \\
- \\
- \\
- \\
\overline{+} \\
+\end{array}$ & $\begin{array}{l}34 \\
21 \\
47 \\
34 \\
32 \\
27 \\
30 \\
37 \\
32\end{array}$ & $\begin{array}{l}79 \\
90 \\
81 \\
71 \\
82 \\
60 \\
71 \\
96 \\
61\end{array}$ & $\begin{array}{r}8 \cdot 7 \\
7 \cdot 4 \\
7 \cdot 6 \\
6 \cdot 5 \\
8 \cdot 8 \\
7 \cdot 4 \\
11 \cdot 2 \\
7 \cdot 3 \\
5 \cdot 9\end{array}$ & $\begin{array}{l}4 \cdot 2 \\
4 \cdot 8 \\
5 \cdot 8 \\
4 \cdot 6 \\
5 \cdot 5 \\
7 \cdot 8 \\
4 \cdot 8 \\
6 \cdot 5 \\
6 \cdot 5\end{array}$ & $\begin{array}{r}64 \\
127 \\
101 \\
73 \\
64 \\
88 \\
85 \\
62 \\
58\end{array}$ & $\begin{array}{l}297 \\
328 \\
546 \\
282 \\
193 \\
267 \\
261 \\
252 \\
119\end{array}$ & $\begin{array}{l}0.215 \\
0.387 \\
0.185 \\
0.259 \\
0.332 \\
0.330 \\
0.326 \\
0.246 \\
0.487\end{array}$ & $\begin{array}{l}29.8 \\
37.5 \\
15.9 \\
12.3 \\
13.4 \\
14 \cdot 2 \\
21.5 \\
19.2 \\
23.7\end{array}$ \\
\hline Mean (SEM) & & & $32.7(2 \cdot 3)$ & $76 \cdot 8(4 \cdot 1)$ & $7 \cdot 87(0.52)$ & $5.61(0.39)$ & $80 \cdot 2(7 \cdot 6)$ & $282 \cdot 8(38 \cdot 7)$ & $0.307(0.03)$ & $20.8(2 \cdot 8)$ \\
\hline
\end{tabular}

*Reference range $11-29 \mathrm{pg} / \mathrm{ml}$.

$\mathrm{FEV}_{1}$-forced expiratory volume in one second; $\mathrm{FVC}$-forced vital capacity; $\mathrm{PaO}_{2}$ - arterial oxygen tension; $\mathrm{PacO}{ }_{2}-$ arterial carbon dioxide tension; GFR - glomerular filtration rate; ERPF-effective renal plasma flow; FF-filtration fraction; AII-serum angiotensin II.

volumes - vital capacity (VC), residual volume (RV), and total lung capacity (TLC)-were estimated by the steady state helium rebreathing technique.

Glomerular filtration rate and effective renal plasma flow were determined by plasma clearance of isotopic tracers. ${ }^{67}$ Filtration fraction was calculated as the ratio of glomerular filtration rate to effective renal plasma flow.

Statistical analysis was by paired Student's $t$ test or Wilcoxon's signed rank test.

\section{Results}

All patients had baseline values of effective renal plasma flow below the age related mean ${ }^{7}$ (table 1). Baseline glomerular filtration rate was relatively well preserved, resulting in an increased filtration fraction. Captopril produced a $17 \%$ greater effective renal plasma flow ( $p<0.005)$ and a $17 \%$ smaller filtration fraction ( $p<0.02)$ than placebo; glomerular filtration rate was unchanged (table 2 ).

Baseline serum angiotensin II was increased in only two patients, neither of whom was receiving maintenance diuretics. All patients showed the anticipated suppression of serum angiotensin II during treatment with captopril ( $p<0.005$ by comparison with placebo).

No significant change was seen in arterial blood gas tensions or spirometric indices between the study periods (table 2). TLCo, KCO, RV, and TLC also showed no significant changes (results not shown).

\section{Discussion}

Although our patients were clinically stable, in most there was a disproportionate reduction in effective renal plasma flow by comparison with glomerular filtration rate and therefore a high filtration fraction. In a previous study a single dose of captopril given to patients with chronic obstructive lung disease caused no change in effective renal plasma flow or glomerular filtration rate. ${ }^{8}$ We have found that 28 days' treatment with captopril produced a small but significant increase in effective renal plasma flow without any change in glomerular filtration rate, resulting in a reduction in filtration fraction. These changes would be expected to promote natriuresis, by reducing sodium and water reabsorption from the proximal convoluted tubule.

Inhibition of angiotensin converting enzyme activity enhances renal sodium excretion in patients with hypertension' or congestive cardiac failure. ${ }^{10} \mathrm{~A}$ single dose of captopril also stimulated natriuresis in salt loaded patients with chronic obstructive lung disease, in the absence of changes in renal haemodynamics," suggesting additional tubular effects of angiotensin converting enzyme inhibition.

Table 2 Mean (SEM) changes in haemodynamic, pulmonary and renal variables following treatment with placebo or captopril in nine patients with chronic obstructive lung disease

\begin{tabular}{|c|c|c|}
\hline & After placebo & After captopril \\
\hline $\begin{array}{l}\text { Body weight (kg) } \\
\text { Supine } \mathrm{HR} \text { (beats/min) } \\
\text { Erect } \mathrm{HR} \text { (beats/min) } \\
\text { Supine } \overline{\mathrm{BP}}(\mathrm{mm} \mathrm{Hg}) \\
\text { Erect } \mathrm{BP}(\mathrm{mm} \mathrm{Hg}) \\
\text { AII }(\mathrm{pg} / \mathrm{ml}) \\
\mathrm{PaO}_{2}(\mathrm{kPa}) \\
\mathrm{PaCO}_{2}(\mathrm{kPa}) \\
\text { FEV }(\% \text { pred) } \\
\text { FVC (\% pred) } \\
\text { GFR (ml/min) } \\
\text { ERPF (ml/min) } \\
\text { Filtration fraction }\end{array}$ & $\begin{array}{c}70 \cdot 6(5 \cdot 7) \\
72 \cdot 9(4 \cdot 5) \\
85 \cdot 1(4 \cdot 9) \\
96 \cdot 1(6 \cdot 8) \\
92 \cdot 2(7 \cdot 1) \\
15 \cdot 6(1 \cdot 5) \\
8 \cdot 08(0 \cdot 65) \\
5 \cdot 90(0 \cdot 34) \\
32 \cdot 1(3 \cdot 1) \\
74 \cdot 2(4 \cdot 8) \\
79 \cdot 1(7 \cdot 6) \\
252 \cdot 1(26 \cdot 3) \\
0.326(0.03)\end{array}$ & $\begin{array}{c}70.7(5 \cdot 7) \\
77 \cdot 0(3 \cdot 5) \\
85.6(4 \cdot 6) \\
99.3(4 \cdot 8) \\
100.8(4 \cdot 3) \\
2.5(1.0)^{* *} \\
8.34(0 \cdot 78) \\
5.67(0.38) \\
32.9(2 \cdot 8) \\
76.3(4.9) \\
77.4(6.5) \\
295 \cdot 7(31 \cdot 5)^{* *} \\
0.269(0.02)\end{array}$ \\
\hline
\end{tabular}

* $p<0.02$ versus value with placebo.

** $p<0.005$ versus value with placebo.

HR-heart rate; BP-mean systemic blood pressure; other abbreviations as in table 1. 
In contrast to earlier, uncontrolled observations, no significant change in pulmonary function was observed. The effect of an angiotensin converting enzyme inhibitor on "lung water" is likely to be less in patients with pulmonary heart disease without clinical decompensation than in those with fluid retention.

In patients with chronic obstructive lung disease and compensated pulmonary heart disease, inhibition of angiotensin converting enzyme activity causes sustained changes in renal haemodynamics that are likely to favour natriuresis. The potential for angiotensin converting enzyme inhibitors to prevent salt and water retention during acute exacerbations of hypoxaemia deserves further study.

We would like to thank Dr G M Sterling for allowing us to study patients under his care and Mrs Susan $O$ 'Toole for nursing assistance.

\section{References}

1 Harvey RM, Ferrer IM, Richards DW, Cournand A. Influence of chronic pulmonary disease on the heart and circulation. Am J Med 1951;10:719-38.

2 Stuart-Harris CH, MacKinnon J, Hammond JDS, Smith WD. The renal circulation in chronic pulmonary disease and pulmonary heart failure. $Q J$ Med 1956 ; 25:389-405.

3 Farber MO, Roberts LR, Weinberger MH, Robertson GL, Fineberg NS, Manfredi F. Abnormalities of sodium and water handling in chronic obstructive lung disease. Arch Intern Med 1982;142:1326-30.
4 Peacock AJ, Matthews AW. The effect of captopril on pulmonary haemodynamics and lung function in patients with chronic airflow obstruction [abstract]. Thorax 1986;41:225.

5 Dusterdieck G, McElwee G. Estimation of angiotensin II concentration in human plasma by radioimmunoassay. Some applications to physiological and clinical states. Eur J Clin Invest 1971;2:32-8.

6 Waller DG, Keast CM, Fleming JS, Ackery DM. Measurement of glomerular filtration rate with Tc-99m DTPA: a comparison of plasma clearance techniques. $J$ Nucl Med 1987;28:372-7.

7 Tauxe WN, Dubovsky EV, Kidd T Jr, Diaz F, Smith LR. New formulas for the calculation of effective renal plasma flow. Eur J Nucl Med 1982;7:51-4.

8 Davies DF, Shock NW. Age changes in glomerular filtration rate, effective renal plasma flow, and tubular excretory capacity in adult males. $J$ Clin Invest 1950;29:496-507.

9 Atlas SA, Case DB, Sealey JE, Laragh JH, McKinstry DN. Interruption of the renin-angiotensin system in hypertensive patients by captopril induces sustained reduction in aldosterone secretion, potassium retention and natriuresis. Hypertension 1979;1:274-80.

10 Kubo S, Nishioka A, Nishimura H, Kawamura K, Takatsu T. Effects of captopril on arterial and venous pressure, renal function, and humoral factors in severe chronic congestive heart failure. Clin Pharmacol Ther 1984;36:456-63.

11 Farber MO, Weinberger MH, Robertson GL, Fineberg NS. The effects of angiotensin-converting enzyme inhibition on sodium handling in patients with advanced chronic obstructive pulmonary disease. $\mathrm{Am}$ Rev Respir Dis 1987;136:862-6. 